\title{
Joanna Antczak-Sokołowska
}

Uniwersytet Gdański

\section{Wpływ terapii dyskursywnej na rozwój kreatywności językowej w komunikacji osób z autyzmem}

\begin{abstract}
[...] Komunikacja była dla mnie jak jednokierunkowa ulica. Rozumiałam, co mówiono do mnie, ale nie mogłam odpowiedzieć. Krzyk i machanie rękami było dla mnie jedyna forma komunikacji... Temple Grandin ${ }^{1}$
\end{abstract}

Zaburzenia komunikacji werbalnej i niewerbalnej wchodzą w skład tak zwanej triady autystycznej [Pisula 2010: 10] ${ }^{2}$. Nawet osoby $z$ autyzmem o wysokim poziomie funkcjonowania poznawczego i językowego mają trudności z prowadzeniem konwersacji, odpowiadaniem na pytania czy z samodzielnym zadawaniem pytań. Czasem, mimo rozumienia mowy, nie potrafią wygenerować odpowiedzi i jedyną ich reakcją są zachowania stereotypowe - jak opisuje to Temple Grandin, autorka książki Byłam dzieckiem autystycznym, popularyzatorka wiedzy na temat autyzmu, pracownik naukowy na Uniwersytecie w Colorado.

Wydaje się, że zagadnienie kreatywnego charakteru języka zupełnie nie dotyczy komunikacji osób z autyzmem, gdyż zachowania językowe, jakie te osoby przejawiają, są najczęściej stereotypowe

1 Cyt. dosłowny za: B. Winczura, Dziecko z autyzmem. Terapia deficytów poznawczych a teoria umysłu, Kraków 2008, s. 40.

2 Są to trzy podstawowe obszary (relacje społeczne, komunikacja, sztywne wzorce zachowań), w których ujawniają się charakterystyczne dla autyzmu nieprawidłowości rozwojowe. 
i sztywne. Artykuł ten stanowi próbę odpowiedzi na pytanie, czy i na ile można w wyniku działań terapeutycznych wzbudzać i rozwijać kreatywność językową w komunikowaniu osób z autyzmem.

W pierwszej części artykułu przedstawię deficyty językowe oraz podstawowe cechy dyskursu u osób dotkniętych autyzmem na tle wyznaczonych przez Renatę Grzegorczykową czterech obszarów, do których odnosi się określenie „kreatywność językowa”. Odwołam się do modelu generatywnego, performatywnych użyć języka, kreatywności manifestującej się w systemie leksykalnym oraz w stwarzaniu światów przedstawionych w różnego typu tekstach [Grzegorczykowa 1995]. W omówieniu tym posłużę się istotnym dla modelu wiedzy językowej Idy Kurcz rozróżnieniem kompetencji językowej i komunikacyjnej [Kurcz 2007]³. Druga część będzie prezentacją tych elementów terapii dyskursywnej, będącej częścią metody terapeutycznej „Dyna Lingua M.S.”, autorstwa Małgorzaty Młynarskiej i Tomasza Smereki, które w moim przekonaniu mogą mieć wpływ na stymulowanie kreatywnych użyć języka w komunikowaniu się osób z autyzmem.

Język ze swej natury ma charakter kreatywny - ze skończonej liczby elementów pozbawionych znaczenia (fonemów) powstają w nim cząstki znaczące (morfemy), które za pomocą odpowiednich reguł (gramatyki) można łączyć w większe ciągi (zdania). Liczba tych ciągów jest nieskończona. Kreatywność jako immanentna cecha języka to jedno z podstawowych założeń teorii Noama Chomskiego. Twórczy aspekt zdolności użytkowników języka, zwanej kompetencją językową, przejawia się w tworzeniu nowych zdań, nigdy przedtem przez nich niewypowiadanych, ani nawet niesłyszanych [Greene 1997: 17]. Model generatywny to pierwszy z wyodrębnionych przez Renatę Grzegorczykową obszarów, których

3 W modelu wiedzy językowej Idy Kurcz wyróżnione zostały dwie podstawowe funkcje języka - reprezentatywna, umożliwiająca przedstawianie (reprezentację) świata zewnętrznego, jak i wewnętrznego w umyśle osób posługujących się językiem, i komunikacyjna, pozwalająca na porozumiewanie się z innymi na temat owych światów. Z tymi funkcjami wiąże się ważne w psycholingwistyce rozróżnienie kompetencji językowej i komunikacyjnej [Kurcz 2007: 103-104]. 
dotyczy określenie „kreatywność języka” [Grzegorczykowa 1995: 14]. Badaczka zwraca wprawdzie uwagę na to, że tworzenie w modelu Chomskiego jest ściśle wyznaczone przez reguły, a więc $w$ jakiś sposób ograniczone, czy nawet automatyczne - przecież w standardowej wersji gramatyki generatywnej wszelkie odstępstwa od reguły (np. wyrażenia metaforyczne) traktowane są jako dewiacja czy błąd. Nie zmienia to jednak faktu, że tak pojmowana kompetencja językowa stanowi dobry punkt odniesienia do ukazania charakteru deficytów językowych w zaburzeniach autystycznych.

Mowa osób z autyzmem jest opisywana przez wielu badaczy bardzo podobnie ${ }^{4}$. Większość podkreśla, że pojawia się ona znacznie później niż u dzieci rozwijających się prawidłowo i od samego początku ma charakter idiosynkratyczny. Najbardziej typowe cechy komunikacji to:

- stereotypie językowe, czyli uporczywe powtarzanie słów, fraz, fragmentów tekstów, zadawanie tych samych pytań,

- echolalie (natychmiastowe bądź odroczone), czyli powtarzanie słów lub zdań wypowiedzianych przez kogoś innego,

- agramatyzmy, czyli mylenie końcówek fleksyjnych, zaimków osobowych,

- trudności w rozumieniu wieloznaczności, wyrażeń metaforycznych,

- zaburzenia prozodii (np. monotonna intonacja).

Już ta krótka charakterystyka językowych zachowań wystarczy, żeby stwierdzić niedorozwój kreatywnego aspektu języka. Według Chomskiego i jego kontynuatorów mówienie to nie odtwarzanie gotowych tekstów czy posługiwanie się gotowymi formułami - jak w wypowiedziach osób $z$ autyzmem - ale tworzenie nowych konstrukcji zdaniowych $w$ celu zakomunikowania zamierzonej przez nadawcę informacji. Ponadto Chomsky twierdzi, że dzieci dzięki wrodzonej zdolności językowej czy wrodzonemu mechanizmowi przyswajania języka na podstawie danych językowych (czyli słyszanych wypowiedzi) samodzielnie tworzą reguły, pozwalające im

4 Korzystałam z opracowań Ewy Pisuli, Barbary Winczury, Tadeusza Gałkowskiego, Małgorzaty Młynarskiej. 
na generowanie nowych zdań. Z reguł tych (to znaczy spośród wielu możliwych gramatyk) wybierają najbardziej odpowiedni do analizowania języka rodzaj gramatyki. Kreatywność jest w modelu generatywnym ściśle związana ze składnikiem syntaktycznym, Chomsky twierdzi nawet, że jest to jedyna jednostka twórcza - składniki fonologiczny i semantyczny mają według niego charakter interpretacyjny [Nivette 1976: 41]. Agramatyzmy w wypowiedziach osób z autyzmem są więc kolejnym potwierdzeniem braku kreatywności językowej. Dzieci autystyczne, poza odtwarzaniem gotowych formuł, często generują wypowiedzi niegramatyczne albo mają trudności w konstruowaniu zdań (czyli ciągów kilkuwyrazowych) w ogóle. Okazuje się, że mechanizm przyswajania języka wygląda u nich trochę inaczej niż założył to w swej teorii Chomsky5. Używają one języka, ale niefunkcjonalnie i nietwórczo (w sensie generatywnym).

Badacze charakterystycznych dla autyzmu zachowań językowych podkreślają deficyty nie tylko w sferze kompetencji językowej, dostrzegają też niedorozwój w zakresie kompetencji komunikacyjnej. Małgorzata Młynarska, charakteryzując dyskurs osób dotkniętych autyzmem, wskazała takie cechy, jak:

- trudności w zrozumieniu intencji komunikacyjnej mówcy,

- oderwanie wypowiedzi od kontekstu sytuacyjnego,

- brak osobistego ustosunkowania się do wypowiadanych i słyszanych treści,

- kłopoty z naprzemiennością wypowiedzi, spontaniczną komunikacją,

- schematyczność dialogów,

- nieumiejętność uwzględniania emocji rozmówców [Młynarska 2006: 879-881].

5 Ciekawą ilustracją tego stwierdzenia mogą być badania nad sposobem zapamiętywania przez dzieci autystyczne bezsensownych ciągów wielowyrazowych. Zauważono, że zarówno dzieci zdrowe, jak i dzieci z autyzmem mają tendencję do zapamiętywania kilku ostatnich słów z ciągu. Sytuacja zmieniała się, gdy w wielowyrazowym ciągu pojawiały się fragmenty, które miały strukturę zdania. Dzieci normalnie rozwijające się zapamiętywały te właśnie części, zaś dzieci z zaburzeniami autystycznymi - nadal ostatnie kilka słów. Okazuje się, że nie wychwytywały one struktury zdania lub nie miała ona dla nich znaczenia. [Frith 2008: 178]. 
Wszystkie te dysfunkcje w sferze kompetencji komunikacyjnej wiążą się $z$ deficytami $w$ tzw. teorii umysłu ${ }^{6}$ czyli umiejętności rozpoznawania i rozróżniania własnych stanów umysłowych, wnioskowania o analogicznych stanach u innych osób, a także przewidywania zachowań ludzi w oparciu o wspomnianą wiedzę. Umożliwiają one sprawne funkcjonowanie $w$ relacjach społecznych i sprawne komunikowanie się, czego brakuje osobom z autyzmem.

Wydaje się, że niedorozwój kreatywnego aspektu języka w obrębie pozostałych trzech obszarów, o których pisała Grzegorczykowa, można powiązać z niedostatecznie wykształconą kompetencją komunikacyjną, a więc z brakiem teorii umysłu.

Rozumienie performatywnych użyć języka wymaga uwzględniania kontekstu społecznego wypowiedzi, intencji nadawczej. Performatywy - zdaniem Grzegorczykowej - stwarzają w świecie stan zobowiązania między nadawcą i odbiorcą [Grzegorczykowa 1995: 14]. Często wiążą się z jakimś rytuałem - choćby religijne wyznanie wiary, odpuszczenie grzechów czy świeckie ogłaszanie wyroku sądowego. Mimo że niektóre zachowania językowe $w$ autyzmie są silnie zrytualizowane, to rytuały te nie mają wpływu na myślenie osób z autyzmem o rzeczywistości, słowo wypowiedziane nie zmienia żadnego stanu rzeczy. Zdarza się wypowiadanie słów, które mogłyby mieć charakter performatywny (np. prośby o wybaczenie). Ale najczęściej brak $w$ tych wypowiedziach uwzględnienia kontekstu sytuacyjnego. Są jak behawioralnie wyuczone reakcje.

Orientacja $w$ językowym obrazie świata utrwalonym $w$ systemie leksykalnym, czyli świadomość tego, jakie cechy zjawisk, obiektów czy relacji między nimi są istotne dla danej społeczności, innymi słowy świadomość tego, że używając danej nazwy, zakładamy, że nasz rozmówca rozumie ją tak jak my, wymaga umiejętności przypisywania innym stanów mentalnych - chociażby rozumienia słów. Uta Frith wskazuję na doniosłą rolę mechanizmu mentalizacji w uczeniu się znaczeń słów [Frith 2008: 132]. Dość częstym problemem osób z autyzmem jest nieumiejętność odczytania

6 Ida Kurcz we wspominanym już artykule uznała moduł teorii umysłu za biologiczną podstawę kompetencji komunikacyjnej [Kurcz 2007: 109]. 
wieloznaczności, rozumienia wyrażeń metaforycznych, konotacji znaczeniowych. Kreatywność językowa ujawniająca się na przykład $w$ dowcipach opartych na wieloznaczności stanowi dla nich barierę komunikacyjną.

Zjawisko kreowania świata $w$ tekstach wiąże się z umiejętnością rozpoznania cech gatunku ${ }^{7}$. Na przykład tworzenie tekstu perswazyjnego wymaga świadomości tego, że można wpływać na przekonania, poglądy czy emocje odbiorców. Skoro osoby autystyczne nie uświadamiają sobie stanów mentalnych innych ludzi, tym bardziej nie potrafią wykorzystać środków perswazji językowej. Z drugiej strony teksty o charakterze perswazyjnym mają dość ograniczony wpływ na osoby z autyzmem. Przykładem może być tak charakterystyczne dla nich powtarzanie tekstów reklamowych w ich dokładnym brzmieniu, bez świadomości, że mają one zachęcić czy nakłonić odbiorcę do kupna jakiegoś produktu. Teksty refleksyjne, które z założenia opierają się na refleksji nadawcy, czyli prezentują jego stany mentalne (przekonania, przeżycia, emocje, przemyślenia), będą przysparzały osobom z autyzmem trudności w odbiorze, a tworzenie takich tekstów wymagałoby od nich świadomości własnych stanów mentalnych oraz umiejętności zwerbalizowania ich.

Deficyty językowe $w$ autyzmie, omówione $w$ pierwszej części artykułu, obejmują zarówno kompetencję językową - w rozumieniu generatywnym, jak i kompetencję komunikacyjną, która wykształca się w rozwoju jednostki na bazie teorii umysłu. Konsekwencją tych deficytów jest brak kreatywności językowej, manifestujący się w różnych obszarach - poczynając od umiejętności generowania nowych zdań zgodnie z regułami gramatycznymi, poprzez niezrozumienie performatywnych użyć języka, problemy semantyczne i słabą orientację $w$ regułach komunikacyjnych różnego typu tekstów.

7 Grzegorczykowa wymienia teksty perswazyjne (propaganda polityczna, teksty reklamowe, kazania) i teksty refleksji filozoficznej oraz poetyckiej. Osobno omawia światy przedstawione $w$ tekstach literackich opartych na fikcji [Gregorczykowa 1995: 18-19]. 
W drugiej części będę starała się pokazać, że dzięki terapii dyskursywnej można - przynajmniej częściowo - uruchomić kreatywny potencjał języka w komunikowaniu się osób z autyzmem.

Terapia dyskursywna jest częścią metody terapeutycznej „Dyna-Lingua M.S." autorstwa logopedki Małgorzaty Młynarskiej i psychologa Tomasza Smereki. [Młynarska, Smereka 2007: 225-231]. Podstawą działań terapeutycznych $w$ tej metodzie jest koncepcja modułowej organizacji funkcji mózgowych. W oparciu o teorię bloków funkcjonalnych Aleksandra turii oraz o jego opis mózgowej organizacji mowy autorzy metody przyjęli podstawowe dla neuropsychologii założenie, że istnieje możliwość kompensowania funkcji słabszych modułów przez moduły sprawniejsze [Młynarska 2008: 116-118].

Ponieważ mózgowy moduł językowy jest związany z modułem teorii umysłu, można za pomocą języka kompensować brak mechanizmu mentalizacji u osób autystycznych. W tym celu najpierw należy skoncentrować się na rozwoju rozumienia przekazów słownych ${ }^{8}$. Jest to nadrzędne zadanie $w$ pierwszym etapie pracy $z$ dzieckiem, zwanym terapią integrującą. Cel ten jest osiągany przez tzw. „zalewanie mową", czyli informowanie o wszystkim, co widać i co ma znaczenie $w$ konkretnej sytuacji. Ważne jest nie tylko to, by nazywać przedmioty, lecz i to, żeby relacjonować zdarzenia z zabarwieniem emocjonalnym. Dzięki temu, oprócz połączenia między bodźcami wzrokowymi i słuchowymi, stymuluje się też odbiór aspektu mentalnego wypowiedzi. Inne techniki stosowane na tym etapie to: rytmogesty, kreacje ruchowe, technika kroków, sznurka lub tasiemki, kolorowych klocków. Wspólnym mianownikiem tych metod jest wspomaganie mówienia poprzez aktywności ruchowe, jak również wykorzystanie bodźców wzrokowych [Młynarska 2008: 202-205].

8 Młynarska twierdzi, że dysfunkcja mózgowego mechanizmu odpowiedzialnego za rozumienie przekazów słownych może stanowić przeszkodę $w$ pracy nad kompensacją deficytu teorii umysłu. Autorka postawiła hipotezę, że niski poziom rozumienia mowy $w$ autyzmie wiąże się z niedostatkiem lub brakiem trwałych połączeń neuronalnych między korą słuchową a korą wzrokową, gdyż słowo nabiera przedmiotowego znaczenia, jeśli jego wzorzec słuchowy ma połączenie z obrazem przedmiotu [Młynarska 2008: 138, 197]. 
Zasadnicza terapia dyskursywna dotyczy mówiących dzieci $z$ autyzmem. Pierwsza jej część to etap konwersacyjny. Skoro podstawowymi deficytami $w$ zakresie kompetencji językowej są automatyzm, sztywność wypowiedzi, a także echolalie, celem pracy terapeutycznej powinno być zdaniem Młynarskiej wygaszanie echolalii i stworzenie $w$ ich miejsce nowego systemu funkcjonalnego, stanowiącego podstawę słownego porozumiewania się [Młynarska 2008: 210]. System ten tworzony jest poprzez wypełnianie pamięci dziecka dużą liczbą wzorców konwersacyjnych, zwanych inaczej schematami dyskursu, skojarzonymi z odpowiednimi sytuacjami interpersonalnymi. Utrwalone schematy stają się $w$ efekcie matrycami, na podstawie których dzieci w nowych sytuacjach tworzą nowe dialogi, podobne do wcześniej ćwiczonych. Mimo schematycznej struktury i treści generowanych wypowiedzi, dzieci zaczynają nawiązywać i podtrzymywać rozmowę $w$ typowych sytuacjach interpersonalnych [Młynarska 2008: 210]. Na tym etapie aktualne pozostają jednak problemy z wyczuciem kontekstu społecznego, intencji i ról komunikacyjnych oraz z uwzględnianiem emocji rozmówcy.

Kolejna część terapii dyskursywnej, nazwana etapem mentalistycznym, polega na redukowaniu tych deficytów. Założenia teoretyczne leżące u podstaw tego etapu to przekonanie, że wiedza o stanach mentalnych i ich wpływie na zachowanie ludzi jest zapisana $w$ języku, tzn. można ją zwerbalizować. Między rozwojem teorii umysłu i rozwojem językowym zachodzą relacje wzajemnego warunkowania. Brak teorii umysłu zaburza aspekt komunikacyjny mowy, jednocześnie mechanizmy poznawcze odpowiedzialne za rozpoznawanie stanów mentalnych bez rozwiniętej mowy nie wystarczą do właściwego rozwoju teorii umysłu. Opierając się na tych założeniach, Młynarska stwierdziła, że istnieje możliwość stworzenia u dzieci autystycznych językowego ekwiwalentu teorii umysłu. Celem pracy terapeutycznej na tym etapie jest rozwijanie mechanizmu refleksji poznawczej, która poprzedza reakcję słowną i działanie oraz mechanizmu refleksji mentalistycznej. Główne narzędzia stosowane w tej części 
terapii dyskursywnej to popularny Test Fałszywych Przekonań a także inne zadania wymyślone przez autorkę i dotyczące wnioskowania o stanach mentalnych innych osób ${ }^{10}$. Każde z zadań składa się z obrazków, przedstawiających konkretne sytuacje, które są omawiane z dzieckiem według schematu: pytanie - odpowiedź. W dialogu sterowanym dochodzi do werbalizacji stanów mentalnych „zakodowanych” w tych sytuacjach"1 ${ }^{11}$ [Młynarska 2008: 217-234]

Tak prowadzona terapia przynosi efekty w postaci umiejętności komunikowania się $w$ typowych sytuacjach interpersonalnych. Młynarska twierdzi, że „poznawczo-językowa treść matryc konwersacyjnych może zastępować $w$ pewnym stopniu zautomatyzowane (u ludzi zdrowych) mechanizmy teorii umysłu, jak mechanizm wspólnej uwagi (...) czy wnioskowanie o stanach umysłu innych ludzi (...)" [Młynarska 2008: 237]. Potwierdzeniem tych tez mogą być badania longitudinalne, prowadzone przez autorkę w latach 1998-2005 oraz studium przypadku chłopca z Zespołem Aspergera.

9 Pierwszą wersją Testu Fałszywych Przekonań było zadanie polegające na odegraniu scenki, w której występują dwie postacie: Sally i Anne. Sally ma koszyk i szklaną kulkę, Anne - pudełko. Sally wkłada kulkę do koszyka i wychodzi. Pod nieobecność Sally, Anne przekłada przedmiot do pudełka. Po powrocie Sally chce się bawić swoją kulką. W tym momencie badający przerywa scenkę i pyta dziecko o to, gdzie Sally będzie szukała swojej kulki. Okazało się, że dzieci z autyzmem udzielały odpowiedzi, z której wynikało, że nie uwzględniają przekonań Sally, mówiły, że będzie szukać w pudełku, zaś większość dzieci normalnie rozwijających się oraz dzieci z Zespołem Downa, które stanowiły grupę kontrolną, twierdziły, ze będzie szukać kulki tam, gdzie ją zostawiła [Frith 2008: 110-113].

10 Są to Testy Domniemanych: Wiedzy, Stanów Emocjonalnych, Umiejętności, Doświadczeń oraz Test Rozpoznawania Mimicznego Wyrazu Emocji i Językowy Test Ról Społecznych [Młynarska 2008: 217-234].

11 Jedynie Test Rozpoznawania Mimicznego Wyrazu Emocji jest przeprowadzany trochę inaczej - każdy wyraz mimiczny prezentowany jest z wypowiedzią, która ilustruje daną emocję. W ten sposób dzieci uczą się rozpoznawania emocji po cechach prozodycznych wypowiedzi i kojarzenia ich z odpowiednim wyrazem mimicznym [Młynarska 2008: 228-229]. 
Analiza wyników badań pokazuje, że w wyniku terapii dyskursywnej dokonuje się znaczny postęp $w$ redukowaniu liczby echolalii natychmiastowych i odroczonych u dzieci z autyzmem. Automatyczna aktywność słowna polegająca na prostym odtwarzaniu słyszanych i zapamiętanych wypowiedzi zmniejsza się, a $w$ ich miejsce pojawia się coraz więcej wypowiedzi o charakterze konwersacyjnym. Dzieci zaczynają generować nowe zdania, których wcześniej nie słyszały, a także prowadzić (nawet inicjować) rozmowy $w$ typowych sytuacjach interpersonalnych [Młynarska 2008: 195-196].

Studium przypadku to opis wielu lat terapii chłopca, który zdobył umiejętności konwersacyjne na wysokim poziomie oraz rozwinął sferę mentalną $w$ stopniu umożliwiającym mu sprawne funkcjonowanie społeczne. Terapię integrującą rozpoczął $w$ wieku czterech lat jako dziecko niemówiące i nierozumiejące mowy, negatywnie nastawione do kontaktów z ludźmi, przez niektórych specjalistów uznane za upośledzone umysłowo.

W wieku 16 lat potrafił kulturalnie rozmawiać z innymi, okazując szacunek rozmówcom i uwzględniając ich wypowiedzi, był zaangażowany $w$ życie swojej rodziny, zorientowany w rzeczywistości oraz w sytuacji politycznej ${ }^{12}$. Według Młynarskiej przyczyną sukcesu chłopca było konsekwentne stosowanie jednej metody terapeutycznej, bardzo rygorystyczne realizowanie indywidualnego programu w terapii i edukacji. Chłopiec ciągle wykazuje pewne deficyty w zakresie teorii umysłu, jednak nie uniemożliwiają mu one funkcjonowania w społeczeństwie [Młynarska 2008: 275-276].

Terapia dyskursywna i poprzedzający ją etap terapii integrującej niewątpliwie wpływają na rozwój kompetencji językowej i komunikacyjnej u osób z autyzmem. W moim przekonaniu uruchamiają też kreatywny potencjał języka. Jest to przede wszystkim kreatywność $w$ rozumieniu generatywnym. To właśnie $w$ wyniku wstępnej fazy integrującej dochodzi do wzbudzenia mowy czynnej

12 Jednym z jego osiągnięć było wystąpienie podczas inauguracji międzynarodowej konferencji logopedycznej, na której wygłosił tekst na temat Auli Leopoldyńskiej, będący streszczeniem przewodnika turystycznego. 
oraz do rozumienia komunikatów słownych. Mówiąc inaczej dzieci zaczynają posługiwać się językiem. To posługiwanie się ma jednak charakter schematyczny, automatyczny, sztywny. Efektem terapii dyskursywnej konwersacyjnej jest redukcja echolalii oraz generowanie nowych zdań. Skutkiem tego etapu jest też opanowanie reguł składniowych - dzieci generują zdania na ogół poprawne gramatycznie.

W terapii dyskursywnej mentalistycznej podejmuje się próby skonstruowania „protezy kompetencji komunikacyjnej” - jak określiła to autorka metody [Młynarska 2008: 171]. Dzięki tej protezie osoby z autyzmem mają sprawniej poruszać się w różnych obszarach zachowań językowych i społecznych. W indywidualnych programach terapeutycznych autorstwa Małgorzaty Młynarskiej i Tomasza Smereki znajdują się propozycje kształcenia takich umiejętności związanych z kompetencją komunikacyjną, jak: mowa dialogowa (adekwatna do sytuacji), wchodzenie w role (ćwiczenie napremienności), werbalizowanie potrzeb i postaw, dyskutowanie, polemizowanie, argumentowanie, przekonywanie. Ponadto $w$ niektórych przypadkach autorzy proponują pracę nad umiejętnościami retorycznymi, pisaniem różnego rodzaju tekstów, budzeniem świadomości metajęzykowej, odczytywaniem znaczenia słów z kontekstu zdaniowego i tekstowego.

Wydaje się, że tak prowadzona terapia może w pewnym stopniu rozwijać kreatywność językową w obrębie pozostałych obszarów wymienionych przez Grzegorczykową. Może przybliżać osoby z autyzmem do rozumienia performatywnych użyć języka, może zwiększać ich orientację $w$ językowym obrazie świata czy niuansach semantycznych lub też $w$ światach przedstawionych $w$ różnego typu tekstach. Jednak pytanie o to, na ile sprawnie mogą się one poruszać w tych obszarach języka, pozostaje nadal otwarte.

Ciekawy jest też wątek relacji między kompetencją komunikacyjną wynikającą z umiejętności mentalizowania a kreatywnością językową. Terapia dyskursywna zasadza się na powiązaniu umiejętności językowych i komunikacyjnych ze sferą mentalną na poziomie neuronalnym. Stymulowanie rozwoju modułu językowego 
prowadzi do wytworzenia się mechanizmów mentalizowania, co zuiększa sprawność komunikacyjną osób z autyzmem i jednocześnie - co starałam się pokazać - rozwija kreatywność językową. Powiązanie to wyrażone zostało też $w$ nieco innym kontekście przez Grzegorczykową, gdy w podsumowaniu artykułu na temat kreatywności językowej stwierdziła, że kształcenie mówienia twórczego, wykorzystującego potencję semantyczną, asocjacyjną czy metaforyczną języka bardzo ściśle wiąże się z kształceniem samodzielnego, twórczego myślenia, które stanowi podstawę kultury umysłowej [Grzegorczykowa 1995: 23].

\section{Bibliografia}

Frith U. [2008], Autyzm. Wyjaśnienie tajemnicy, Gdańskie Wydawnictwo Psychologiczne, Gdańsk.

Gałkowski T. [2003], Zaburzenia komunikacji w autyzmie, [w:] Logopedia. Pytania i odpowiedzi, Gałkowski T., Jastrzębowska G. (red.), Wydawnictwo Uniwersytetu Opolskiego, Opole.

Greene J. [1977], Psycholingwistyka. Chomsky a psychologia, Państwowe Wydawnictwo Naukowe, Warszawa.

Grzegorczykowa R. [1995], Jak rozumieć kreatywny charakter języka?, [w:] Kreowanie świata $w$ tekstach, Pajdzińska A., Tokarski R. (red.), Wydawnictwo Uniwersytetu Marii Curie-Skłodowskiej, Lublin.

Kurcz I. [2007], Autyzm a wiedza językowa człowieka, [w:] Afazja i autyzm: zaburzenia mowy oraz myślenia, Młynarska M., Smereka T. (red.), Wrocławskie Towarzystwo Naukowe, Wrocław.

Młynarska M. [2008], Autyzm w ujęciu psycholingwistycznym, Wydawnictwo Uniwersytetu Wrocławskiego, Wrocław.

Młynarska M., Smereka T. [2007], Metoda „Dyna-Lingua M.S.” Małgorzaty Młynarskiej i Tomasza Smereki $w$ terapii zaburzeń mowy i myślenia, [w:] Afazja i autyzm: zaburzenia mowy oraz myślenia, Młynarska M., Smereka T. (red.), Wrocławskie Towarzystwo Naukowe, Wrocław.

Nivette J. [1976], Zasady gramatyki generatywnej, Ossolineum, Wrocław.

Pisula E. [2010], Autyzm. Przyczyny, symptomy, terapia, Harmonia, Gdańsk.

Winczura B. [2008], Dziecko z autyzmem. Terapiadeficytów poznawczych a teoriaumysłu, Impuls, Kraków. 